\title{
Loss of military equipment by the SADF at the Battle at Indungo during the Border War, 31 October 1987
}

\author{
Marius Scheepers and Fransjohan Pretorius \\ Department of Historical and Heritage Studies, University of Pretoria
}

\begin{abstract}
This article takes the form of an investigation regarding the loss of military equipment by the South African Defence Force (SADF) at the Battle at Indungo, in an operation that was assigned the codename Operation Firewood, on 31 October 1987 during the Angolan Border War. The war was waged from 1966 to 1989 in Southern Africa. The case study of Operation Firewood illustrates some of the circumstances under which the SADF lost military equipment in Angola during the war.

Operation Firewood was one of more than 300 SADF general operations ${ }^{201}$ that occurred in Angola. In the final stages of the war, the area north of Cuvelai provided the setting for the launching of Operation Firewood, some 285 kilometres north of the border with South West Africa/Namibia. The aim of this military operation was to eliminate an enemy base that housed elements of the People's Liberation Army of Namibia (PLAN), the military wing of the South West Africa People's Organisation (SWAPO).
\end{abstract}

\section{Introduction}

Travelling through southern Angola, one is reminded of a period in the history of this country when it was entrapped in a bitter civil war between its liberation movements. There was also a 'second war' on the Angolan border with South West Africa/Namibia for the liberation of Namibia. The SADF carried out operations on both fronts.

More than 30 years after these wars had ended, the Angolan landscape is still littered with discarded military vehicles of all sorts, from both sides of the divide. During the Angolan Border War, the abandoning of military equipment by the SADF was a rare occurrence. Today, a few SADF military vehicles are on display at a military site in Luanda.

The former Union of Soviet Socialist Republics (the Soviet Union), along with some of the countries that formed the Communist Bloc in Eastern Europe during the Cold War, were the main suppliers of weapons, equipment and armaments to FAPLA or People's Armed Forces for Liberation of Angola and SWAPO. 


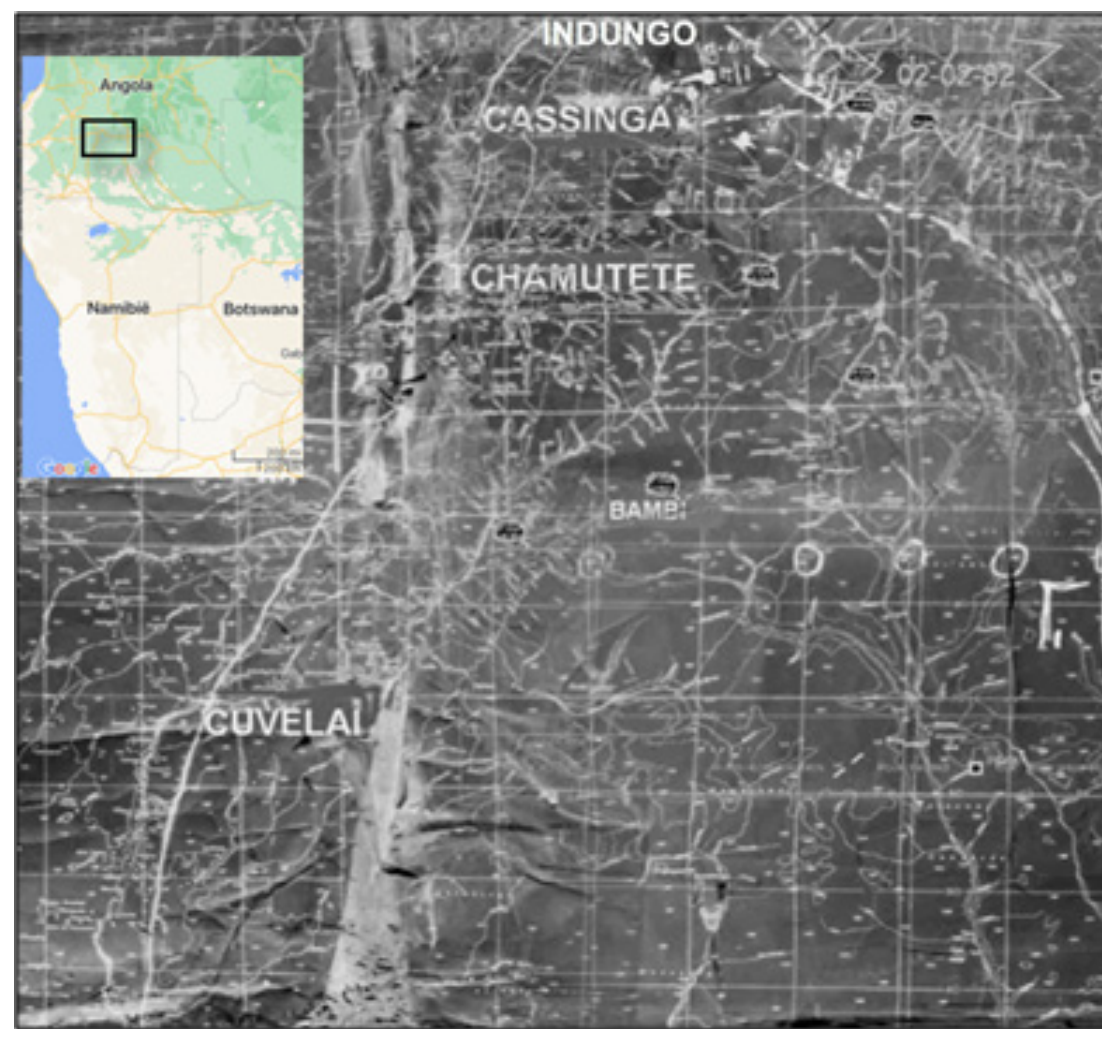

Figure 1: Map of the Angolan Border War during the carrying out of Operation Firewood in the deep central area of southern Angola in 1987. The background map is the original operational map that was displayed at 32 Battalion headquarters during operations. ${ }^{202}$

During the civil war in Angola, the MPLA or People's Movement for the Liberation of Angola was in control of the capital city, Luanda, and large areas in the north, east and centre of the country. FAPLA served as the military wing of MPLA, which was supported by the Cuban Revolutionary Armed Forces and the Defence Force of the Soviet Union.

The main objective of the SADF during the war, which was also the motivation for carrying out Operation Firewood, was to prevent SWAPO forces from entering South West Africa/Namibia in large numbers. ${ }^{203}$

Since 1976, the SADF had conducted cross-border operations inside Angola regularly. Each year, the primary objective of the larger operations of the SADF was to search for, attack, and destroy SWAPO targets and bases before infiltrations by SWAPO were due to commence at the end of the year. 
SWAPO needed to establish its operational headquarters and other bases close to the border between South West Africa/Namibia and Angola in order to provide supplies and support to infiltrating SWAPO soldiers. For SWAPO to have an effective guerrilla force, its soldiers needed to operate in areas in close proximity to South West Africa/Namibia, to enable them to be within easy reach of their targets, to cause damage to infrastructure, and to influence local populations. During the last stages of the war, SWAPO's missions required of them to leave their bases, which were situated deep in Angola, and to travel on foot over distances of more than 300 kilometres, before they reached South West Africa/Namibia. ${ }^{204}$

SWAPO guerrilla bases were located close to FAPLA and Cuban bases, where SWAPO sought protection from frequent attacks by the SADF. The FAPLA forces put up much more resistance when they were attacked than their SWAPO counterparts, because they were divisions of a regular army, which defended its bases with heavy weapons, such as the Soviet-built T-34/85 and T-54/55 tanks, which were often used defensively. The SWAPO forward bases probably served as assembly points for SWAPO guerrillas, from which they were deployed to infiltrate into South West Africa/Namibia.

SWAPO usually chose to forfeit their bases when they were attacked. An attack by the SADF during Operation Colosseum on 13 November 1986 was a case in point, as SWAPO dispersed yet again. ${ }^{205}$ An attack by an SADF task force on the SWAPO base at Indungo was to have a significantly different outcome, as the SWAPO force stood its ground and retaliated. When the SADF task force withdrew after the attack on Indungo, it abandoned three Casspir armoured troop carriers and a Buffel mine protected vehicle (MPV), which subsequently fell into the hands of SWAPO.

There are a number of similarities between Operation Firewood of October 1987 and Operation Colosseum (1986). Both operations took place at approximately the same time of year. Both task forces were formed from companies of 2 and 5 Reconnaissance Regiments. Their respective SWAPO targets were almost identical, and were situated in the same general area. At least one unit from 5 Reconnaissance Regiment used Casspir armoured personnel carriers during both operations, and Colonel JR (James) Hills, who was to command the carrying out of Operation Firewood, would inevitably have made some observations concerning the carrying out of operations under these circumstances from his previous experience.

\section{Operational instructions and phases of Operation Firewood}

For Operation Firewood, the SADF was to field arguably its best-trained military formations, which were to be merged into a formidable task force. Whether the units succeeded in performing as a united force during the operation needs to be evaluated in due course. It consisted of the South African Special Forces units from its Reconnaissance Regiments (Recces), 1 Parachute Battalion (Parabats) and companies from 101 Battalion, which was generally referred to as the 'Ovambo' battalion, because its soldiers were recruited from the Ovambo region of South West Africa/Namibia, from the same people as SWAPO soldiers. ${ }^{206}$ Other units, such as 32 Battalion (the Buffalo 
Battalion) and $61 \mathrm{Mechanised} \mathrm{Battalion}(61 \mathrm{Mech})$, also gained excellent track records during the war. But 32 Battalion and 61 Mech were already being deployed as a segment of the task force for another operation, Operation Modulêr, in the Mavinga area, some 100 kilometres to the east of Indungo.

An order from the SADF Army Headquarters in Pretoria, which bore the title "Op Instruksie 36/87", declared that the General Officer in Command of the SA Army Forces: South West Africa "should inflict maximum losses upon the PLAN forces in the central and eastern areas, south of the Cubango River, during the period 1 November 1987 to 30 November 1987 '. ${ }^{207}$

The target at Indungo was the Central Area Headquarters of SWAPO. The Eastern Area Headquarters of SWAPO was found to be situated five kilometres to the north of the enemy base near Indungo, although only a small group of from 40 to 60 SWAPO soldiers were expected to be at their base during the attack. ${ }^{208}$ The Eastern Area Headquarters were obviously not as well defended as the Central Area Headquarters. According to sources, both headquarters were at the target area at the Indungo base. ${ }^{209}$ While the Eastern Area Headquarters housed only a small component of SWAPO soldiers, the Central Area Headquarters housed a much larger SWAPO force. Although the size of this force remains uncertain, the fierce resistance that it put up during the long, drawn-out battle at Indungo, suggests that the size of the force was substantial. At the conclusion of the engagement, the encounter yielded a correspondingly substantial body count of between 100 and 150 SWAPO soldiers, which was recorded by the various units of the task force.

It was planned that Operation Firewood was to be carried out by adhering to the procedures that had been prescribed for the following phases: ${ }^{210}$

Phase 1 was to be the preparatory phase, which was to be carried out from 30 September until 26 October 1987. During this period, the force was to assemble at Oshivelo in South West Africa/Namibia, where it would prepare and receive training for the operation.

At the commencement of Phase 2, the SADF task force was to infiltrate Angola from 26 October to 1 November 1987, through Rundu headquarters, which were situated in Sector 20, in South West Africa/ Namibia. The force had to cross the Angolan border and follow the northern route, which runs parallel to the Cubango River. On their arrival at the headquarters of the Tactical Operations frontline base of the SADF at Ionde, the members of the task force were to be provided with logistical support, fuel and other provisions.

During Phase 3, which was also known as Operation Firewood A, the task force had to locate the Central Area Headquarters of PLAN and attack the target, thereby carrying out Operation Firewood B, before commencing area operations from 8 November to 30 November 1987. 
During Phase 4, the force had to withdraw from Angolan territory from 30 November to 4 December 1987, before demobilising.

The SADF task force was instructed to carry out the operation -

And ensure the safety of the members of the SADF who participated in the operation, while their equipment was to receive high priority and to serve as a criterion against which the successful conclusion of the operation was to be measured. Significant risks were to be limited. ${ }^{211}$

The task force comprised a battalion-strength force of 1071 soldiers, ${ }^{212}$ which is generally considered a formidable force.

The 159 vehicles of the main SADF force for the attack at Indungo consisted of 81 from 5 Reconnaissance Regiment and 78 from 101 Battalion. Included in this number were the vehicles of the members of the Citizen Force from 2 Reconnaissance Regiment, who travelled in three Buffels, while the two platoons from D Company of 1 Parachute Battalion had eight Buffels. Their C Company, which was deployed as a reserve force, was also issued with Buffels. There were a further four Ratel 81 mortar-equipped infantry fighting vehicles and a variety of logistical vehicles, recovery vehicles and field ambulances. ${ }^{213}$ It was imperative that the task force maintain a high level of mobility. Its vehicles needed to be sufficiently reliable to allow its troops to reach the target at Indungo without any disruptive breakdowns, after travelling over long distances on uneven terrain. Before they made contact with the enemy, the SADF forces debussed from their vehicles, leaving them behind to apprehend the enemy on foot. This strategy was standard for the motorised infantry soldiers of the SADF for fighting a guerrilla force.

A fourth unit, 101 Battalion, was to operate in a supporting role for the main attacking force. Each of the four companies of 101 Battalion was divided into four teams, and each team was equipped with four Casspirs. As the command Casspir brought the total for each company to 17 , the four companies of 101 Battalion fielded 68 Casspirs altogether. In addition, the Casspirs were augmented by a further ten vehicles. Consequently, 101 Battalion was not fully integrated with the main force, which had to launch the attack at Indungo.

The larger component of the SWAPO force was absent, conducting military exercises at the Tobias Hanyeko Training Centre at Lubango. ${ }^{214}$ Large numbers of SWAPO soldiers began arriving at the Indungo base during the battle, only to come immediately under SADF fire, with severe casualties being inflicted.

During the planning for the attack by the task force, the leader group constructed a sand model of the layout of the SWAPO base, which depicted the main features of the target area according to scale. Its features included:

- the main road, which ran from north to south;

- the T-junction at which the access road towards the enemy base at Indungo joined the main road; 
- the direction of the access road towards the base;

- the size of the target area, all according to scale; and

- the large Vinjamba Shona or marsh, which lay to the south of the base.

On the main road, there were at least four low-water bridges where the road crossed dry riverbeds and small ditches. As the base at Indungo was surrounded by shonas on three sides and the access road from the west, the decision to attack it from this direction by following the access road was not a difficult one to make. In addition, the model included representations of the locations of the temporary operational headquarters and the medical post to the west of Indungo, and of the area in which the vehicles of the echelon were to remain, at a safe distance further away to the south. ${ }^{215}$

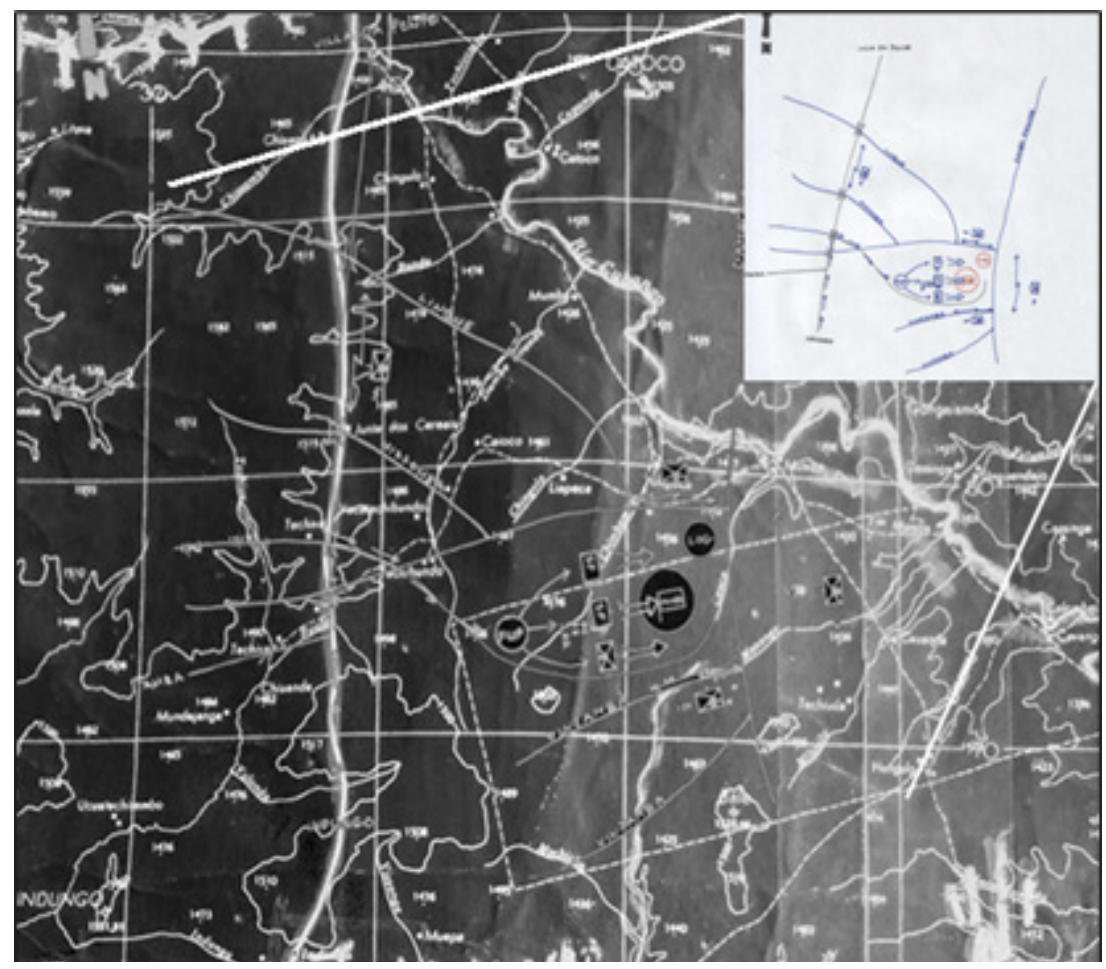

Note: The inserted map is a sketch of the area that is not according to scale (Chris Snyman $)^{216}$.

Figure 2: Map of the SWAPO base at the battle at Indungo on 31 October 1987 during Operation Firewood. The background map is the original operational map that was displayed at 32 Battalion headquarters during operations.

Source: Museum of Military History, Johannesburg. 


\section{The attack by the main task force}

On 31 October 1987, before the attack by the main task force commenced, the vehicles that were to be used in the attack on the main target area formed up in a specific order. The soldiers of 51 Recce Commando were mounted in their own four Casspirs. To their right, were the Casspirs of 52 Recce Commando; further right was 53 Recce Commando, while still further right, were the three Buffels of the Citizen Force detachment from 2 Reconnaissance Regiment, and on the far-right flank, were another eight Buffels, which carried soldiers from D Company of 1 Parachute Battalion. The force was supported by a mortar group of four Ratel 81 mortar-equipped infantry fighting vehicles. The Casspirs of the four 101 Battalion reaction force companies had to patrol the area to the north, east and west of Indungo.

The H-hour for the attack, which commenced with an air strike, was 12:00. ${ }^{217}$ The SAAF fighter jets dropped their bomb loads, withdrew and immediately left the area. ${ }^{218}$ The plan for the attack by the main task force entailed applying overwhelming force while chaos still prevailed at the target area in the aftermath of the air strike.

Owing to the fierce resistance that the main attacking force of the task force encountered during the engagement, the battle could probably be considered one of the most bitterly contested of the war. ${ }^{219}$ Consequently, progress was exceedingly slow. When the Recces and Parabats encountered a trench, they broke into it, fired with their RPG-7s and bombarded the enemy with more $60 \mathrm{~mm}$ mortars.

The first fatality suffered by the Parabats occurred when Corporal Nico Smith Olivier, 19 years of age, died from a wound to the neck area when he debussed from a Buffel. According to information received from a personal account, ${ }^{220}$ the two platoons of the Parabats were positioned in the centre of the main force when the fighting started. Accordingly, it is likely that they came under the heaviest SWAPO assault in the form of small arms fire and exploding mortar bombs. The Parabats remained in their line as they moved towards the target, traversing an area approximately 500 metres wide.

When they arrived at another large open area, which resembled a military parade ground, they again came under fierce enemy small arms fire. Due to a lack of cover of any sort, five paratroopers were killed. ${ }^{221}$ Lance Corporal Raymond Mark Light (21) was the next soldier to die, in this case from a wound to his chest. During a period of probably not more than an hour, four more Parabats were mortally wounded. Riflemen Hugues Norbert de Rose (21), Wayne Valentine Ewels, (21) and Dirk Willem van Rooyen (20) died during the attack. Rifleman Jean Mark Schuurman (21), who had also been seriously wounded during the fighting, later succumbed to his wounds while he was being transferred to a military hospital by an aircraft. ${ }^{222}$

A Buffel from 2 Recce Regiment was immediately knocked out after having taken a direct hit from a rocket fired from a B-10 recoilless gun. The soldiers who had been in the vehicle earlier were extremely fortunate, as they all survived the explosion, although a few sustained multiple shrapnel wounds. ${ }^{223}$ 
The main attacking force succeeded in maintaining its forward momentum, which was crucial in any motorised attack on fortified SWAPO camps. Although the men were able to clear the enemy trenches by carrying out mopping-up drills, at 15:00, they encountered fierce resistance from enemy soldiers who were hiding in trenches ${ }^{224}$ to the south-west of the target area. ${ }^{225}$ The Recces were ordered to perform a final sweep of the area and to leave. After they had accomplished their mission, they withdrew from the area. ${ }^{226}$

\section{The captured and destroyed Casspirs}

As an official military report confirms, three destroyed Casspirs from 101 Battalion were not recovered from an area to the north of Indungo. ${ }^{227}$ Corporal Trevor (Tandekas) Stander's abandoned Casspir, from call sign 33B, was subsequently discovered by FAPLA and placed on public display for propaganda purposes. It was riddled with bullet holes, although the vehicle appeared to have remained fairly intact. A large opening, which could have been caused only by the explosion of a rocket from a B-10 gun, was visible on the side of another Casspir. An intelligence officer from the Recces, Second Lieutenant Dylan C Cobbold, was killed inside this vehicle by the explosion. ${ }^{228}$ At least two Casspirs were destroyed beyond recognition as a result of hits by rockets from either B-10 recoilless guns or exploding RPG-7 rockets. The events that were to result in the loss of personnel and military vehicles by 101 Battalion require adequate investigation.

From the available evidence, it appears that the first incident in the operation to affect 101 Battalion directly during its deployment could have occurred when some vehicles of call signs 31, 32 and 32C were attacked when they drove into a SWAPO ambush to the north of the main target area. ${ }^{229}$ In this incident, the soldiers under Second Lieutenant AC (David) Bock (call sign 32) and Corporal Stander (call sign 33B) served as early warning groups. They were deployed in the area to the north of the target at Indungo, where they patrolled in an easterly direction. Although the soldiers who were with Bock and Stander came under heavy mortar and small arms fire in the ambush, they returned fire with the .50 calibre Browning machine guns that were mounted on their vehicles. The predicament in which Bock found himself was exacerbated as a consequence of some of his soldiers being wounded and others dismounting from their vehicle and hurriedly fleeing the scene, in an attempt to escape certain death from enemy fire. ${ }^{230}$ Bock and Stander continued to fire on the SWAPO force, in order to protect their wounded soldiers, as these men refused to abandon the soldiers where they lay alongside the destroyed vehicles. After the fighting had died down, the men under Bock were the last soldiers from the task force to remain at the scene. ${ }^{231}$

As the unit had suffered a number of fatalities and injuries and its Casspirs had been destroyed by enemy fire, call sign 32 requested support from its company. ${ }^{232}$ The men who served under Captain Andries H de B (Radies) Rademeyer, the company commander (call sign 30), left their positions east of the target area, probably after their commander had received orders from Commandant JK (Jaco) Kruger for call sign 30 to make its way towards the position that Bock was holding. The group that Rademeyer commanded was heavily armed: sixteen Casspirs were fitted with .50 calibre $(12.7 \mathrm{~mm})$ and .30 calibre $(.303$-inch or $7.62 \mathrm{~mm})$ Browning machine guns and its soldiers carried an array of small arms. ${ }^{233}$ 
The Casspirs that were destroyed and abandoned by the SADF at Indungo had been assigned to Captain Rademeyer (call sign 11) and Second Lieutenant Deon Botes (call sign 33C). The causes of these losses also warrant further investigation. At 16:00, Rademeyer's convoy drove in an extended line formation in a westerly direction alongside a shona towards the main road. ${ }^{234}$ As Rademeyer had difficulty in establishing radio communication with his headquarters by means of his small radio, he requested Botes, who had radio contact, to pass his messages on to headquarters. When it encountered an obstacle in its path, the convoy was forced to form up in a single line. At that moment, it was attacked in an ambush by SWAPO soldiers, ${ }^{235}$ which resulted in the convoy coming under heavy fire from RPG-7 rockets and machine guns. ${ }^{236}$

To the north-east of the target area, a commotion erupted and the Casspirs of Rademeyer and Botes, which had become bogged down in an ambush, were destroyed as a result of direct hits by enemy fire. ${ }^{237}$ Rademeyer and a soldier quickly abandoned their vehicle, while another soldier remained inside it. The soldiers in the other Casspirs attempted to come to the rescue of the wounded soldiers, but their progress was hindered when the tyres of their vehicles were damaged and deflated to the rim as a result of intense enemy fire. ${ }^{238}$ Stander, in the call sign 33B Casspir, assumed command of the remaining vehicles of call signs 31 and $32 .{ }^{239}$

While Rademeyer was embroiled in the SWAPO ambush, a terrifying noise was heard over the radio network from someone who was obviously in great distress, screaming, "Help! Help! They are killing us, they are killing us!" The caller was Second Lieutenant Cobbold, one of the Recces whose Casspir had accompanied that of Rademeyer and an officer of Colonel Hills' home unit. ${ }^{240}$ If Colonel Hills had not been apprised earlier by his senior staff of the impending crisis at the positions of 101 Battalion to his north, hearing these cries on the internal radio network would surely have drawn his attention to it immediately. Hills' immediate reaction to the call could not be established in interviews with members of his staff who had been close to him, as they appeared to be prepared to provide only scant details concerning Hills' role in the operation. One inference that could be drawn was that the only likely reason for Hills' apparent failure to respond immediately, by devising a plan to rescue the soldiers, was that Commandant JK Kruger, the commander of 101 Battalion, had assumed full responsibility for the welfare of his men. Accordingly, the answer to the question that this assessment raises, namely whether the task force operated as an integrated unit during the operation, would be a resounding 'no'.

Other related events are equally deserving of attention. Personnel in vehicles of call sign 42 of 101 Battalion were instructed to join up with Lieutenant NJA (Seis) Prinsloo and Corporal Justin Theunissen (call sign 20), to provide support and render assistance to the call signs that were under attack by SWAPO. They arrived at the contact area at almost the same time as call sign 10 under Captain Koos Maritz. Call sign 10, which was positioned to the south of the company under the command of Rademeyer, was also requested to provide reinforcements to the beleaguered convoy. ${ }^{241}$ Maritz was accompanied by Corporal DL (Wikus) Cronjé, a Recce intelligence operative. ${ }^{242}$ According to Cronjé, when their Casspir came under small arms fire, Maritz sustained two gunshot wounds 
from bullets that went through one of his arms, which left him unconscious. Although he was obliged to assume command of the men who had been under the command of Maritz, Cronjé was unable to staunch the severe bleeding from the wounds. ${ }^{243}$

After some time had elapsed, call sign 10 left the scene of the contact, but damage to its tyres resulted in the Casspir becoming bogged down. After Maritz had been rescued by Prinsloo, he was taken to the medical post, where his wounds were treated and his life was saved. ${ }^{244}$ When call signs 10 and 42 arrived at an open shona area, the Casspirs formed up in an extended line formation. They charged forward through a shona and passed a hill on their way towards the SWAPO positions. The purpose of the feint was to draw the attention of SWAPO away from the Casspirs in Rademeyer's convoy.

The troops under the command of Maritz also came under attack from SWAPO soldiers. Corporal Cronjé saw a few SWAPO men jumping onto a Casspir that was adjacent to the one in which he was travelling, while the vehicles were in motion. SWAPO had employed this tactic in the past, when they had endeavoured to force Casspirs of the SADF to stop by opening their rear doors in order to throw hand grenades into them. In this instance, the SWAPO small arms fire bounced off the sides of the armour of the Casspirs. ${ }^{245}$ Had the attempt by the SWAPO soldiers succeeded, the men in the Casspir would have been killed. Although the SWAPO soldiers exposed themselves to a great deal of risk by attempting to destroy the Casspirs in this manner, their unorthodox methods were foiled by Maritz's men.

As the fighting continued, Lieutenant Pierre (Blikkies) Blignaut (call sign 11) also assisted Rademeyer and Botes. ${ }^{246}$ Blignaut's .50 calibre Browning machine gun was immediately rendered unserviceable when the turret on which it had been mounted was destroyed by a direct hit from an RPG-7 rocket. Blignaut's vehicle was a mere 50 metres away from where Rademeyer and Botes were last seen. As a result of the hit, Blignaut sustained a wound to his right arm, while Sapper Casper Steyn, who had accompanied him, was killed instantly. Blignaut managed to continue firing his R-4 rife with his left arm, abandoning his Casspir and fleeing under heavy enemy fire towards the Casspir of Botes. He sustained a further wound, as a result of a sliver of shrapnel that became lodged in his eye, for which he received treatment upon arriving at the medical post. Although Botes (call sign 33C) abandoned his vehicle just moments before it burst into flames from the explosion of an enemy rocket, his body was engulfed in flames and he died next to his burning vehicle. ${ }^{247}$

Although Lieutenant Cobbold survived the ordeal that had elicited his desperate cries for help over the internal radio network, he became yet another casualty when his Casspir suffered a direct hit by B-10 rockets after driving directly into a well-positioned SWAPO ambush. The men who attempted to recover his body came upon the lifeless body of Captain Rademeyer, lying some distance from his vehicle, under a bush beside a large pile of discarded cartridge cases. ${ }^{248}$ One of his arms had been severed by enemy fire and he had died as a consequence of severe blood loss. ${ }^{249}$

Next to arrive at the scene of Blignaut's plight was Corporal JJ (Bronkies) Bronkhorst (call sign 11C), who rushed to his rescue. ${ }^{250} \mathrm{He}$ was joined by Casspirs of call sign 40 , 
which also arrived at the scene at high speed. Using their Casspirs as weapons, the SADF drivers drove directly into a group of SWAPO soldiers, who perished under the large tyres of their vehicles. Bronkhorst's driver also proceeded to drive into another group, which comprised at least seven heavily armed SWAPO soldiers, who had been carrying a variety of RPG-7 rockets and machine guns. Bronkhorst suffered a wound from a bullet, which had entered and exited one of his arms. ${ }^{251}$ Sergeant Lappies Labuschagne sustained two broken ribs when his Casspir smashed into more SWAPO soldiers, pulverising them against the side of a large anthill..$^{252}$

The vehicle of Second Lieutenant Marco (Velle) Smit, call sign 13 of 101 Battalion, took a direct hit from an RPG-7 rocket, which left both his gunner and his driver dead. ${ }^{253}$ Smit continued to urge his driver to proceed forward, unaware that he was already dead. Under severe fire from SWAPO RPG-7 rockets, Smit also abandoned his vehicle. The men under Smit were too shocked and disoriented to carry on fighting at this point. In a display of outstanding presence of mind, initiative and leadership in combat, Smit seized an R-4 rifle from one of his bewildered soldiers, with which he managed to kill some enemy soldiers. ${ }^{254}$

Another significant incident that concerned 101 Battalion occurred after the men under Captain Rademeyer had been ambushed by a SWAPO group. Corporal Chris Snyman, WO1 Chris Schutte (call sign 22C), the vehicles of Lieutenant Prinsloo and Corporal Theunissen of call sign 20 and the men of call sign 42 under Captain Van Niekerk were sent to render assistance. They drove on the left side of the main road in an extended line formation, anticipating that they would make contact with the SWAPO group that had attacked the soldiers under the command of Second Lieutenant Bock. ${ }^{255}$ As they experienced a great deal of difficulty in maintaining their formation, the vehicles soon started moving off in different directions. Prinsloo and Theunissen opened fire at an enemy BM-14 truck that was fleeing the scene. It was quickly destroyed. ${ }^{256}$

Driving in the extended line formation, they pushed northwards along the road that would take the convoy to the position of the beleaguered vehicles of the men under Bock. As some vehicles left the road, they were obliged to make sharp right turns. ${ }^{257}$ Theunissen, accompanying them in a Casspir, was unaware of the sudden change of direction. He proceeded along the road, but soon realised that he was driving alone towards the positions of the enemy. He made an abrupt turnabout and beat a hasty retreat.

Theunissen was later awarded the distinguished Honoris Crux medal for the bravery that he had demonstrated by continuing to drive while under severe enemy fire. His was one of five such medals awarded for action in Operation Firewood. ${ }^{258}$ According to the report that served as the motivation for making the award, he had endangered his own life by committing to a course of action that saved the lives of several other SADF soldiers.

\section{Probable explanation for solid defence by SWAPO}

The SWAPO soldiers were sufficiently trained to enable them to fire their rockets with accuracy and precision. It seems likely that the experience that they had acquired during Operation Colosseum the previous year had provided them with an opportunity to 
learn some valuable lessons. The SWAPO soldiers were clearly far more resilient and much better prepared to defend themselves against an attack during the carrying out of Operation Firewood than they had been the previous year. ${ }^{259}$

In the meanwhile, SWAPO soldiers who were busy performing routine military training exercises and rehearsals in an area to the north of the Indungo base attacked Rademeyer's convoy. When they heard the clamour of the attack on the main target area, they immediately dispatched their anti-tank platoons to engage in defensive action. These SWAPO soldiers were all heavily armed, each carrying a number of RPG-7 and RPG-75 rockets. They approached Rademeyer's convoy and engaged the vehicles by rapidly firing their rockets, reloading and firing again in rapid succession. Owing to the rapid rate at which the rockets could be fired, the superior design of the RPG launcher as a weapon for destroying armour and the ability of SWAPO to master the weapon, the SWAPO soldiers succeeded in destroying several SADF vehicles. Many rockets found their targets, penetrated the armoured steel of the Casspirs and detonated inside of them, setting them alight. ${ }^{260}$

The detachment of SWAPO soldiers - who had been to the north of the main target area - unexpectedly crossed paths with the Casspirs of Rademeyer and Botes, after which an intense firefight broke out. Had the SWAPO soldiers not encountered the Casspirs, they might have passed them undetected and would have been able to join the forces at the main target area and provided much-needed reinforcements to fend off the main attack of the task force. By being at the wrong place at the wrong time, the Casspirs of 101 Battalion were able to halt this advancing force, thereby saving the lives of many SADF soldiers at the main target area. ${ }^{261}$

\section{The retreat by the task force from Indungo}

As darkness approached rapidly, the rear end of the task force convoy managed to join up with the remainder of the vehicles and proceeded with recovery procedures until 20:00. The task force was able to recover three or four Casspirs that had been set ablaze by enemy artillery fire. The vehicles then made their way to the logistical area, where their occupants endeavoured to maintain silence until midnight. ${ }^{262}$

Owing to the enormous difficulty that the task force had experienced in recovering abandoned Casspirs that had not been accounted for and preventing them from falling into the hands of the enemy and the impossibility of returning to the target area near Indungo to do so, some drastic measures were needed. On 1 November, the SAAF launched another air strike on the target area. According to a report by Colonel EG Viljoen from Sector 10, two Impala Mk II attack aircraft conducted the air-to-ground attack at the Central Area Headquarters of SWAPO, "to destroy logistical positions". ${ }^{263}$ This euphemism tends to suggest that the actual purpose was to destroy the SADF vehicles that had been left behind at Indungo. It is unclear how many of the abandoned vehicles were successfully destroyed beyond recognition by the air strike. A photograph of FAPLA soldiers standing next to an intact Casspir at Indungo provides evidence that at least one had remained unscathed. ${ }^{264}$ 


\section{The captured Buffel}

While the task force was withdrawing from the target area in the aftermath of the operation, a call sign 22B Buffel vehicle drove into a large hole, overturned, and landed on its side. The excavation resembled the bunkers that had been prepared to hide a tank in the hull-down position. As the occupants of the Buffel were not injured in the accident, they were able to board another vehicle. ${ }^{265}$

According to the report of the SADF, the task force was unable to recover or destroy the stricken vehicle, ${ }^{266}$ and the intact Buffel, together with its camouflage net and some equipment, was left behind at the target area. The abandoned Buffel was a significant find for FAPLA, and the vehicle was also later displayed at Luanda. ${ }^{267}$

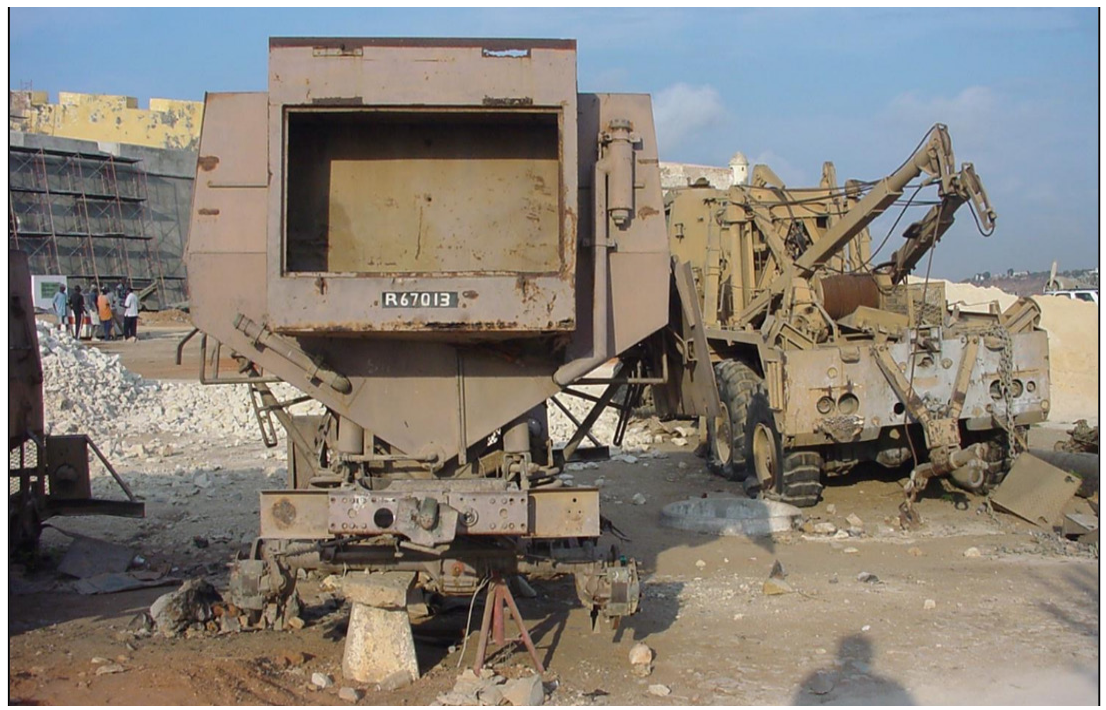

Figure 3: Photograph of a Buffel and Withings recovery vehicle that were displayed at Luanda after the war. The Buffel is probably the vehicle which the SADF abandoned at Indungo. ${ }^{268}$

In total, four SADF vehicles were abandoned at Indungo, including the three Casspirs of Stander, Rademeyer and Botes. The fact that the SADF troops did not attempt to salvage movable equipment from the stricken Buffel suggests that they could have felt severely pressed for time or even panicked and left the area in haste, fearing a counter-attack by a large SWAPO contingent.

\section{Other accounts of the forfeiture of military vehicles to FAPLA by the SADF}

The above was not the first occasion on which a Buffel was captured by the enemy. At a meeting at Lubango on 13 September 1987, several weeks before the battle at Indungo, FAPLA announced that a SADF Buffel MPV and an Eland 90 armoured car 
had been captured and put on display. ${ }^{269}$ This Buffel was obviously the vehicle that had been captured on 2 September 1987, near Cuamato. ${ }^{270}$ The Eland 90 armoured car was among five armoured vehicles that had been abandoned by the SADF more than a decade before, on 23 November 1975, during the carrying out of Operation Savannah at Ebo. ${ }^{271}$ Apart from these vehicles, a SADF recovery vehicles is also on display at a military exhibition in Luanda, Angola.

The SADF task force DF lost an intact Buffel to the enemy in an ambush at Caiundo on 18 December 1983, while it was carrying out Operation Askari. ${ }^{272}$ On 15 August 1986, in the aftermath of the cancellation of Operation Alpha Centauri, the SADF was forced to destroy with explosives and abandon the wreckage of a Withings recovery vehicle and a Kwêvoël 100 transport vehicle on the Chambinga Heights, in an attempt to avoid their capture by the approaching FAPLA force. ${ }^{273}$

On 6 September 1987, during the carrying out of Operation Modulêr, a column of FAPLA's $59^{\text {th }}$ Brigade located the position of a 32 Battalion Recce team. The men from 32 Battalion joined a team of the Chief Staff Intelligence in beating a hasty retreat. They left behind a Casspir and a Withings recovery vehicle, which fell into the hands of FAPLA. A week later, a Ratel armoured vehicle from 32 Battalion was abandoned after it had been completely obliterated at the Lomba River, during the fiercest fighting of the war, while the detachment was participating in Operation Modulêr. ${ }^{274}$ A few months later, on 24 March 1988, three SADF Olifant $105 \mathrm{~mm}$ tanks were left abandoned in a minefield during the last days of the fighting at the Tumpo triangle, west of Cuito Cuanavale, during the carrying out of Operation Packer. ${ }^{275}$ This particular loss of armoured equipment was to be a huge propaganda coup for the Cubans and FAPLA once the war had ended. On 26 June 1988, during the fighting south of Techipa in the south-west of Angola, the SADF also lost and left behind a destroyed Ratel $90 \mathrm{~mm}$ armoured vehicle. ${ }^{276}$

These incidents account for between 16 and 20 SADF vehicles that were damaged beyond repair and abandoned in Angola during the 23-year-long Angolan Border War, but which are still reasonably recognisable as military equipment. While some of these vehicles were left behind still intact, the abandoned wreckage consists of either large pieces of vehicles, such as undercarriages, or large portions of them. The makes of some of these vehicles are known, as the SADF abandoned them while they were still intact. Some vehicles remain to this day at various locations in Angola where they were abandoned.

\section{Explaining the loss of vehicles}

During an official military debriefing on 15 March 1988, which was chaired by Brigadier FJ (Frank) Bestbier on behalf of the Chief of the SADF, a report was presented, which covered a wide range of topics pertaining to Operation Firewood. The four vehicles the SADF lost at Indungo undoubtedly formed part of the discussion that followed. ${ }^{277}$

The debriefing was also intended to generate an accurate evaluation of how effectively the SADF had managed to strike at an enemy base that was situated deep in southern 
Angola. Relevant considerations included the size of the task force that had been deployed and the long distances over rough terrain over which the force had been obliged to travel before it could launch the attack on the target that had been identified at Indungo. ${ }^{278}$

The instructions for the carrying out of the operation by the Recces originated from a number of directives that specifically required the Recces to lead the assault on Indungo. According to the directive:

The forces which were to participate in the operation were to consist of BG Special Forces, provided by BG SA Army Forces SWA, from its own sources. No additional support was to be provided by the Republic of South Africa. ${ }^{279}$

The Recces were tasked with most of the fighting duties, although their principal function was generally not considered to entail assuming roles that were normally assigned to infantry soldiers. The Recces were highly trained in sophisticated military disciplines that included reconnaissance, locating enemy positions, and demolishing military and strategic installations in locations that were far behind enemy lines. They operated in small teams, which seldom comprised more than four men. ${ }^{280}$ They were not intended to fight in fixed formations as members of large forces. The costs training of Recce operators entailed were considerably higher than those that were incurred for the training of soldiers to perform more conventional roles. Consequently, losing any Recce operators in abortive attacks on SWAPO bases entailed severe loss with respect to expertise, and required a considerable investment in terms of time and money to locate and train replacements. As it turned out, the losses that the Recces had suffered by the end of Operation Firewood amounted to only one soldier.

At least two more sets of losses were recorded during the war, when the Recces attacked SWAPO bases while assuming the roles of regular rifle infantry soldiers. Operation Colosseum in 1986 has already been mentioned in this article. In addition, during the carrying out of Operation Kropduif in 1977, 90 soldiers were selected from 1, 2, 4 and 5 Recce Regiments for an attack on a SWAPO base at Eheke. Seven Recces were killed during the engagement. ${ }^{281}$ The participants at the military conference ${ }^{282}$ did not debate the decision to include the Recces in Operation Firewood, although many senior officers held fairly strong views concerning where the true strengths of the Recces lay, and did not believe they should have been used in regular infantry roles.

By 1987, the SADF was making full use of its Casspir armoured vehicles. At Indungo, 101 Battalion deployed 68 and lost 3 Casspirs. If certain measures had been put in place during the planning of the operation, these losses might not have occurred.

The Casspir was designed and built specifically to cope with the types of rough terrain and treacherous conditions that were encountered by the task force en route to the target area. Normally, a Casspir could be pushed to its limits and still be relied upon to perform adequately under extremely adverse conditions. During the carrying out of Operation Firewood, the tortuous journey to the target area had to expose the inherent 
weaknesses of these extraordinary vehicles, and breakdowns were the inevitable consequence of pushing them beyond their limits. Some features of the Casspir's design made it vulnerable during enemy attacks. At Indungo, the tyres of several vehicles were punctured, and their main weapons did not function properly. Due to its limited application as a combat vehicle, Casspirs should not have been deployed in the front line when an enemy base was attacked.

In terms of durability, Casspirs were not in the same class as the Ratel armoured vehicles of the SADF. Although Casspirs were cheaper to manufacture and maintain, the Ratels were considerably tougher, as an Afrikaans idiomatic expression suggests. The English translation of 'so taai soos 'n ratel' is 'as tenacious as a honey badger'. Consequently, it should not be surprising that the report submitted by Commandant JK Kruger concerning Operation Firewood included a request that the more resilient Ratel armoured vehicles should replace the Casspirs in future operations. ${ }^{283}$ The standard infantry vehicles that were issued to 101 Battalion, the Recces and the Parabats when Operation Firewood was carried out did not include any of the sophisticated Ratels, but were rather the more common Casspirs and Buffels. Motorised infantry units were not trained to perform in mechanised infantry roles during operations. It was not anticipated at the time that 101 Battalion would undergo mechanised infantry training for some time to come. The war soon drew to a close, before the wish that Commandant JK Kruger expressed for his infantry unit to be provided the opportunity to be trained in mechanised warfare, could be realised.

Another difficulty arose as a consequence of deploying Casspir armoured vehicles and Buffel MPVs during the same operation, as the designs and specifications of the two types of vehicles were significantly different. ${ }^{284}$ Owing to the narrower axle length of the Buffels, they encountered a great deal of difficulty in attempting to follow in the tracks that the Casspirs had left behind. The difficulties arose due to the deep tracks that the Casspirs imprinted in the soft sand in Angola. The Buffels also had smaller engines than the Casspirs, which made it difficult for them to keep up with the faster Casspirs. In addition, the Buffels made slower progress while driving through densely wooded areas, owing to their limited bush-breaking ability, by comparison with progress made by the better-suited Casspirs. It needs to be emphasised that operational planning should have taken adequate cognisance of the likelihood of such an eventuality. Like any other large army of its kind at the time, the SADF did not standardise its range of different vehicles with respect to axle size.

The Ratel 81 mortar-equipped infantry fighting vehicles were not the weapons of choice for the operation, because they were not able to deliver intense firepower and they could not inflict sufficient damage on the enemy at the commencement of and during an attack. The preferred weapons would rather have been larger artillery pieces, such as the 140 mm G-2 Howitzer guns and the greatly favoured $127 \mathrm{~mm}$ Multiple Rocket Launchers mounted on Unimog vehicles. Although Colonel EG Viljoen, the Senior Staff Officer: Operations at the military Sector 10 headquarters at Oshakati, who had formerly served as the commanding officer of 32 Battalion, had requested General Kat Liebenberg, the Chief of the South African Army at the time, to equip the task force with Multiple 
Rocket Launchers for the operation, the request was refused. ${ }^{285}$ Consequently, the task force was obliged to attempt to make do with the $81 \mathrm{~mm}$ mortars that were supplied.

Those present at the debriefing in 1988 also gave due consideration to the lack of the type of support that artillery guns could have provided to the task force. ${ }^{286}$ The support provided by fire from $81 \mathrm{~mm}$ mortars on Ratel 81 mortar-equipped infantry fighting vehicles had proved to be largely ineffective, despite the perceived suitability of the highly mobile Ratels for operations, such as Operation Firewood. In addition, the 127 mm Multiple Rocket Launchers that would have enabled the task force to respond effectively to the tactics of SWAPO had not been available for Operation Firewood. ${ }^{287}$ On the other hand, artillery guns, such as the $140 \mathrm{~mm} \mathrm{G}-2$ howitzer, were not suitable for operations that were carried out deep in Angolan territory, as it was not possible to transport the guns over such long distances.

There were several expressions of surprise at the military conference in $1987^{288}$ concerning the ability the enemy had displayed in launching effective counter-attacks against the task force of the SADF. ${ }^{289}$ Although the spirited resistance of the SWAPO forces was considered a rare occurrence during the Angolan Border War, the SWAPO soldiers had proved themselves to be well disciplined, as they had responded not by fleeing, but by engaging 101 Battalion with a high level of commitment. ${ }^{290}$ By 1987 , PLAN was a far better trained force than it had been at the beginning of the war, and it was able to make effective use of its anti-tank teams against the Casspirs. The SWAPO soldiers were able to fire rapid volleys of RPG-7 rockets and they used the more advanced Czech-manufactured RPG-75 rockets, which had disposable lightweight tubes. These weapons and the B-10 recoilless guns provided their anti-tank teams with massive firepower, which enabled them to damage or destroy many Casspirs. The .30 and .50 Browning machine guns that were intended to protect the Casspirs and their crews were not sufficient to prevent SWAPO from launching successful counter-attacks. ${ }^{291}$

The delegates at the debriefing in 1987 also considered whether the main objective of Operation Firewood had been achieved, namely to prevent SWAPO forces from entering South West Africa/Namibia in large numbers. ${ }^{292}$ In the final analysis, the answer to the question was a resoundingly affirmative one, as the ability of SWAPO to infiltrate during the approaching annual rainy season had received a severe blow, and infiltrating SWAPO soldiers had once again been thwarted. SWAPO continued to operate from bases that were situated far deeper inside Angola. ${ }^{293}$

It was also quite unprecedented that an SADF force should leave vehicles and equipment behind after carrying out an operation. As has already been discussed, with the exception of a few operations, after almost every attack on SWAPO bases, the SADF forces retrieved all of their damaged vehicles. Operation Firewood was unique in this respect, as the task force had left the Indungo area before all of its vehicles could be accounted for. $^{294}$

A final analysis is provided in paragraph $15 . \mathrm{b}$ of a document that bears the reference number OPS/070/311/31, in which the manner in which 101 Battalion was deployed during the attack is described as having been 'highly dangerous' ${ }^{295}$ This assessment 
indicates that the higher command disapproved of the risks that had been incurred during the deployment of the soldiers of 101 Battalion during the carrying out of the operation. It must have had a direct bearing on the decision to deploy 101 Battalion in enemy territory deep inside Angola. There can be no doubt that 101 Battalion was well suited to performing as a reaction force. Its soldiers were well trained to track the spoor of fleeing SWAPO soldiers in dense bush during follow-up operations. They were even able to overcome mild resistance when SWAPO led their vehicles into ambushes. The SADF commanders, who were well trained in combat, should have known that it would not be advisable for 101 Battalion to operate in areas where SWAPO had retained the upper hand, as its vehicles were not protected against the anti-tank weapons that SWAPO had at its disposal. Senior officers who planned the operation were, perhaps, overconfident, and might have underestimated the strength of SWAPO forces, which was evident at SWAPO bases deep in Angola.

From a careful analysis of the conditions that prevailed during the carrying out of Operation Firewood, it becomes evident that a number of different factors contributed to the loss of vehicles and the casualties that 101 Battalion suffered. The soldiers of some of the platoons of 101 Battalion that participated in Operation Firewood were inadequately trained, as the platoons comprised mainly new recruits. The relative rawness (i.e a lack of proper preparation and training before an attack on a SWAPO base) of the soldiers provides a plausible explanation for their inability to check the surprise attacks by SWAPO soldiers. Most of the companies of 101 Battalion were already being deployed as a segment of the task force for another operation, Operation Modulêr, in the Mavinga area. It seems likely that the companies of 101 Battalion that were deployed in the task force for Operation Firewood were made up of soldiers from sections that had not been selected to participate in the other operation and that they were deployed for Operation Firewood because they were the only soldiers who were available.

This official military report of 1987 also acknowledged that the operations of the SADF that had been carried out under similar conditions as those of Operation Firewood (which entailed attacking enemy targets deep in southern Angola) had been extremely difficult to accomplish. One of the operations to which the report referred in this context was probably Operation Colosseum, in which the SADF forces suffered a similar fate. During both of the operations, the vehicles of the task forces were subjected to a great deal of punishment, such as travelling great distances over difficult and uneven terrain. During both operations, the recovery of damaged and destroyed vehicles from the remote areas where the operations had been carried out, was extremely difficult. ${ }^{297}$

At the battle at Indungo, 15 SADF soldiers were killed and 56 were wounded. These figures reflect, arguably, the highest numbers of casualties that the SADF suffered in a single day during the entire Angolan Border War. ${ }^{298}$ Apart from the names of the six Parabats who were listed among the dead, the other casualties were:

- $\quad$ Second Lieutenant Dylan Chevalier Cobbolt (26);

- $\quad$ Captain Andries Hercules de Bruyn Rademeyer (27);

- $\quad$ Second Lieutenant Deon Botes (20); 
- $\quad$ Sapper Erasmus Albertus Steyn (19);

- Rifleman B Abrahams (25)

- Rifleman V Petrus (21);

- Rifleman P Epafu

- Rifleman T Sheepo; and

- Rifleman M Vuushona.

The ages of the last three are unknown..$^{299}$

\section{Conclusion}

The number of vehicles that were lost at Indungo during Operation Firewood, together with the vehicles that were lost in Angola during other operations that have been covered briefly in this article, amount to between 16 and 20 SADF vehicles. This figure represents the total number of vehicles that were still fairly recognisable as military equipment, which had been damaged beyond repair and abandoned in Angola during the 23 year-long Angolan Border War. ${ }^{300}$ It is the considered opinion of the authors of this article that these figures, place the loss of four vehicles at Indungo in a realistic perspective. Here, the SADF paid a high price in the form of military equipment which was captured by the enemy. 


\section{ENDNOTES}

${ }^{201}$ J Geldenhuys. Ons was daar: Wenners van die oorlog om Suider-Afrika. Pretoria: Kraal, 2012, 66.

${ }^{202}$ Source: Museum of Military History, Johannesburg.

${ }^{203}$ Department of Defence Archives, File HLeer/d OPS/309/1 OP Firewood B, Nabetragting, par 7.e, 1 December 1987.

${ }^{204}$ Department of Defence Archives, H Leer/D Sein/UG/309/1/OP Firewood B, 15 March 1988.

${ }^{205} \mathrm{~K}$ Stadler. Recce: Kleinspan-operasies agter vyandelike linies. Cape Town: Tafelberg, 2015, 265.

${ }^{206}$ M Scheepers. "The Battle at Indungo, 31 October 1987: An SADF military venture against SWAPO in the Angolan Border War". MA thesis. University of Pretoria, 2019.

${ }^{207}$ Department of Defence Archives, File HLeer/d OPS/309/1 op. cit., p. 1. (Translated from the Afrikaans text)

${ }^{208}$ Department of Defence Archives, OPS/070/311/31 October 1987, 312300B, par 7.

${ }^{209}$ Department of Defence Archives, H Leer/D Sein/UG/309/1 op. cit., par 6.a.iii, 6.a.iv; Department of Defence Archives, FIK/070 31 October 87, par 7.

${ }^{210}$ Department of Defence Archives, File HLeer/d OPS/309/1 op. cit.

${ }^{211}$ Department of Defence Archives, File HLeer/d OPS/309/1 op . cit., par 3.g;

${ }^{212}$ Department of Defence Archives, H Leer/D Sein/UG/309/1 op. cit.

${ }^{213}$ Department of Defence Archives, File HLeer/d OPS/309/1 op. cit., par 5.b.iii; according to an unidentified report that does not have a heading, there were 153 vehicles.

${ }^{214}$ Department of Defence Archives, H Leer/D Sein/UG/309/1 op. cit.

${ }^{215}$ LJ Bothma. Anderkant Cuito: 'n Reisverhaal van die Grensoorlog. LJ Bothma, 2011; Chris Snyman, personal interview, 16 March 2019, when reference was made to par 4.b of the appendix to the report on the reflection of Operation Firewood.

${ }^{216}$ Corporal Chris Snyman served at 101 Battalion in 1987. He accompanied 101 Battalion's Regimental Sergeant Major Chris Schutte. During the battle at Indungo, they were stationed with the logistical vehicles to the south of the target area. They received orders to patrol the area south of the base at a shona marsh, to look for any signs of SWAPO soldiers approaching the target area from outside of the base. At some stage during the battle, they received an urgent request on their radio from Maritz to assist his sections, which were at locations to the north of Snyman's group, and to evacuate some wounded soldiers from the command post to a safe area on the main road. Snyman made detailed observations during the battle, when he took part in the evacuation of wounded soldiers. He made a valuable contribution to this article.

${ }^{217}$ Department of Defence Archives, FIK/070 op. cit.

${ }^{218}$ Department of Defence Archives, File HLeer/d OPS/309/1 op. cit., par 6.b.iii; recollection by Wickus Cronjé.

${ }^{219}$ The Pretoria News. 3 November 1987.

${ }^{220}$ Johan Kruys, company commander of 1 Parachute Battalion, personal interview, 18 May 2021.

${ }^{221}$ Department of Defence Archives, File MED 10/UG/309/1 OP Firewood, February 1988, CF Scheepers collection box 10 ; an unidentified report that does not carry a heading.

${ }^{222}$ Kruys, personal interview, 18 May 2021.

${ }^{223}$ Department of Defence Archives, OPS/070/311/31 op. cit., par 6; Department of Defence Archives, File HLeer/d OPS/309/1 op. cit., par 6.b.vii; Department of Defence Archives, H Leer/D Sein/UG/309/1 op. cit.; Department of Defence Archives, FIK/070 op. cit., par 5; Kruys, personal interview, 19 May 2019.

${ }^{224}$ Kruys, personal interview, 19 May 2019. 
${ }^{225}$ Department of Defence Archives, OPS/070/311/31 op. cit., par 7; Department of Defence Archives, File HLeer/d OPS/309/1 op. cit., par 6.b.vii; Kruys, personal interview, 19 May 2019.

${ }^{226}$ Christo Roelofse, company commander of 5 Reconnaissance Regiment, personal interview, 26 October 2018.

${ }^{227}$ Department of Defence Archives, OPS/070/311/31 op. cit., par 10; Department of Defence Archives, FIK/070 op. cit., par 10; Department of Defence Archives, H Leer/D Sein/ UG/309/1 op. cit.; Department of Defence Archives, File HLeer/d OPS/309/1 op. cit., par 6.b.xiii (both reports state that three burning Casspir vehicles were recovered); Snyman op. cit., when reference was made to the annexure to the report concerning the reflection upon Operation Firewood; reference was also made to par 2 and 7.b of the explanatory notes and par 5 of Appendix 2 to the annexure to the report concerning the reflection upon Operation Firewood. According to par 19.b of the report, four Casspirs were recovered, three of which had been totally destroyed. As it was later confirmed from photographs, the third Casspir remained completely intact. According to par 20.a of Appendix 1, at midnight, six Casspirs were towed by other types of vehicles. In addition, according to par 19.b, the last remaining three Casspirs were left behind at 20:00, owing to heavy bombardment of the area by the enemy

${ }^{228}$ Snyman op. cit.

${ }^{229} \mathrm{Ibid}$., when reference was made to par 9 and 14 of Appendix 1 and par 1 of the appendix that provides explanatory notes to the report concerning the reflection upon Operation Firewood.

${ }^{230}$ I Uys. Cross of Honor. Germiston: Uys, 1992, 134; Snyman op. cit., when reference was made to par 6 of Appendix 1 of the annexure that contains the report concerning the reflection upon Operation Firewood.

${ }^{231}$ Snyman op. cit.

${ }^{232}$ Uys op. cit., p. 134; Snyman op. cit., when reference was made to par 2 of the appendix titled "Explanatory notes" and par 16-18 of Appendix 1, the annexure that contains the ${ }^{233}$ Snyman op. cit. report concerning the reflection upon Operation Firewood.

${ }^{234}$ Department of Defence Archives, OPS/070/311/31 op. cit., par 8; Department of Defence Archives, File HLeer/d OPS/309/1 op. cit., par 6.b.x; Snyman op. cit., when reference was made to par 2 of the appendix titled "Explanatory notes" in the annexure that contains the report concerning the reflection upon Operation Firewood.

${ }^{235}$ Uys op. cit., p. 134; Snyman op. cit., when reference was made to par 1 of the appendix titled "Explanatory notes" in the annexure that contains the report concerning the reflection upon Operation Firewood.

${ }^{236}$ Department of Defence Archives, OPS/070/311/31 op. cit., par 8; Department of Defence Archives, File HLeer/d OPS/309/1 op. cit., par 6.b.x; Snyman op. cit., when reference was made to par 2 of the appendix titled "Explanatory notes" to the annexure that contains the report concerning the reflection upon Operation Firewood. According to the report, the Casspirs of call signs 33, 33B and 39s were hit by RPG-7 rockets.

${ }^{237}$ Snyman op. cit.

${ }^{238}$ Uys op. cit., p. 134; Snyman op. cit., when reference was made to par 2 of the appendix titled 'Explanatory notes' and par 17.b and 17.c of Appendix 1 to the annexure to the report upon the reflection of Operation Firewood.

${ }^{239}$ Uys op. cit., p. 134; Snyman op. cit., when reference was made to par 2 of the appendix titled "Explanatory notes" and par 17.a and 17.d of Appendix 1 to the annexure to the report concerning the reflection upon Operation Firewood.

${ }^{240}$ Snyman op. cit. 
${ }^{241}$ Uys op. cit., p. 134; Snyman op. cit., when reference was made to par 3 of the appendix titled "Explanatory notes" attached to the annexure to the report concerning the reflection of Operation Firewood. The report incorrectly places Maritz with call sign 30.

${ }^{242}$ Uys op. cit., p. 134.

${ }^{243}$ Ibid., p. 134; Department of Defence Archives, PERS OPS/705/1 Nov 87.

${ }^{244}$ Corporal DL (Wickus) Cronjé, personal interview, 31 October 2017.

${ }^{245}$ Ibid.

${ }^{246}$ Snyman op. cit., when reference was made to par 4 of the Appendix called explanatory notes attached to the annexure to the report on the reflection of Operation Firewood.

${ }^{247}$ Uys op. cit., p. 134.

${ }^{248}$ Ibid.

${ }^{249}$ Snyman op. cit.

${ }^{250}$ Uys op. cit., p. 134; Snyman op. cit., when reference was made to par 4 of the appendix titled "Explanatory notes" attached to the annexure to the report concerning the reflection of Operation Firewood.

${ }^{251}$ Department of Defence Archives, Pes/542/13 Nov 87.

${ }^{252}$ Snyman op. cit.

${ }^{253}$ Snyman op. cit., when reference was made to par 4.b of the appendix titled "Explanatory notes" to the annexure to the report concerning the reflection upon Operation Firewood. According to this report, the other two call signs that were hit by RPG rockets were call sign 11, according to par 4.a, and call sign 11B, according to par 4.c of the appendix titled "Explanatory notes".

${ }^{254}$ Snyman op. cit.

${ }^{255}$ Snyman op. cit., when reference was made to par 1 of Appendix 1 and par 6 of the appendix titled "Explanatory notes" to the annexure to the report concerning the reflection upon Operation Firewood.

${ }^{256}$ Uys op. cit., p. 135; Snyman op. cit., when reference was made to par 18.d of Appendix 1 and par 1 of Appendix 2 to the annexure to the report concerning the reflection upon Operation Firewood. The report states that that three enemy soldiers were killed and one was captured while they attempted to flee the area.

${ }^{257}$ Snyman op. cit., when reference was made to par 18.b of Appendix 1 to the annexure to the report concerning the reflection upon Operation Firewood.

${ }^{258} \mathrm{https}$ ://wiki2.org/en/Honoris_Crux_(1975)\#Recipients; Uys op. cit., p. 134. Uys incorrectly cites a sixth soldier who received an Honoris Crux medal. Although he might have been associated with 101 Battalion, he did not participate in Operation Firewood.

${ }^{259}$ Stadler op. cit., p. 265.

${ }^{260}$ Snyman op. cit.

${ }^{261}$ Ibid.

${ }^{262}$ Ibid.

${ }^{263}$ Obie Oberholzer, personal interview, 31 October 2017; Department of Defence Archives, OPS385/03 Nov 87, par 5.c.iv.

${ }^{264}$ Snyman op. cit.

${ }^{265}$ Kruys, personal interview, 19 May 2019; Snyman op. cit.

${ }^{266}$ Department of Defence Archives, OPS/070/311/31 op. cit., par 10.

${ }^{267}$ Department of Defence Archives, FIK/070 op. cit., par 10.

${ }^{268}$ Source: The source of the photograph is unknown.

${ }^{269}$ Department of Defence Archives, INL/833/08 Sep 87.

${ }^{270} \mathrm{Ibid}$.

${ }^{271}$ Department of Defence Archives, Opsomming Ops Foxbat; S du Preez. Avontuur in Angola: Die verhaal van Suid-Afrika se soldate in Angola 1975-1976. Pretoria: Van Schaik, 1998, 137. 
${ }^{272}$ M Scheepers. Striking inside Angola with 32 Battalion. London: Helion, 2012, 98.

${ }^{273}$ W Steenkamp \& H Heitman. Mobility conquers: The story of 61 Mechanised Battalion Group 1978-2005. London: Helion, 2016, 708; P Stiff. The silent war: South African recce operations, 1969-1994. Alberton: Galago, 1999, 536.

${ }^{274}$ P Nortje. The terrible ones: A complete history of 32 Battalion (Vol 1 \& 2). Cape Town: Zebra Press, 2012, 991; F Bridgland. The war for Africa: Twelve months that transferred the continent. Gibraltar: Ashanti, 1990, 84.

${ }^{275}$ Bridgland op. cit., p. 330.

${ }^{276}$ Scheepers op. cit., p. 128.

${ }^{277}$ Department of Defence Archives, H Leer/D Sein/UG/309/1 op. cit.

${ }^{278}$ Ibid.

${ }^{279}$ File HLeer/d OPS/309/1 op. cit.

${ }^{280}$ Stadler op. cit.

${ }^{281}$ Stiff op. cit., p. 199

${ }^{282}$ Department of Defence Archives, H Leer/D Sein/UG/309/1 op. cit. This document, dated 1 December 1987, is the report of a military conference held at the South African Army Headquarters in Pretoria.

${ }^{283}$ Snyman op. cit., when reference was made to par 5.a of the annexure to the report concerning the reflection upon Operation Firewood.

${ }^{284}$ Department of Defence Archives, File HLeer/d OPS/309/1 op. cit., p. A-5.

${ }^{285}$ Ibid.

${ }^{286}$ Department of Defence Archives, File HLeer/d OPS/309/1 op. cit., par 7.d.i, p. A-5.

${ }^{287}$ Snyman op. cit., when reference was made to par 5.b of the annexure to the report on the reflection of Operation Firewood.

${ }^{288}$ Department of Defence Archives, H Leer/D Sein/UG/309/1 op. cit. This document, dated 1 December 1987, is the report of a military conference held at the South African Army Headquarters in Pretoria.

${ }^{289} \mathrm{Ibid}$.

${ }^{290}$ Department of Defence Archives, File HLeer/d OPS/309/1 op. cit., par 7.b.ii.

${ }^{291}$ Department of Defence Archives, H Leer/D Sein/UG/309/1 op. cit.

${ }^{292}$ Department of Defence Archives, File HLeer/d OPS/309/1 op. cit., par 7.e.

${ }^{293}$ Department of Defence Archives, H Leer/D Sein/UG/309/1 op. cit.

${ }^{294}$ Snyman op. cit.

${ }^{295}$ Department of Defence Archives, OPS/070/311/31 op. cit., par 14.g.

${ }^{296}$ Ibid., par 14.h.

${ }^{297}$ Ibid., par 15.b.

${ }^{298}$ Department of Defence Archives, File MED 10/UG/309/1 op. cit.; Department of Defence Archives, an unidentified report that does not carry a heading.

${ }^{299}$ Department of Defence Archives, PERS OS/159/10/10 Nov 87.

${ }^{300}$ Mathematical calculation of the incidents shown higher up of confirmed SADF vehicle losses in Angola. 